\title{
Investigating Foreign Language Learning Anxiety Among Yemeni University EFL Learners: A Theoretical Framework Development
}

\author{
Amr Abdullatif Yassin ${ }^{1,2} \&$ Norizan Abdul Razak ${ }^{1}$ \\ ${ }^{1}$ Faculty of Social Sciences and Humanities, Universiti Kebangsaan Malaysia, Malaysia \\ ${ }^{2}$ Centre of Languages and Translation, Ibb University, Yemen \\ Correspondence: Amr Abdullatif Yassin, Centre of Languages and Translation, Ibb University, Yemen. E-mail: \\ amryassin84@gmail.com
}

Received: December 25, $2016 \quad$ Accepted: September 11, $2018 \quad$ Online Published: September 13, 2018
$\begin{aligned} & \text { doi: 10.5539/elt.v11n10p38 } \\ & \text { URL: http://doi.org/10.5539/elt.v11n10p38 }\end{aligned}$

\begin{abstract}
This study aimed at investigating the level of foreign language anxiety experienced by Yemeni University EFL students. Although many scales have been developed to measure the level of anxiety, each scale investigates anxiety in one skill except Foreign Language Classroom Anxiety Scale (FLCAS) which investigates anxiety mainly in speaking and listening. The current study developed a new scale called Foreign Language Anxiety Scale (FLAS) which fused the three scales with modifications in order to investigate the level of anxiety in the four skills. This scale scored .807 in Cronbach's Alpha Validity test. The participants are 155 Yemeni University students and the results of the analysis revealed that $13 \%$ of the students experienced high level of anxiety, $69 \%$ experienced moderate level of anxiety, and $18 \%$ experienced low level of anxiety. The general level of anxiety among Yemeni university EFL students is moderate as they score 138 out of 240.
\end{abstract}

Keywords: language learning, English as a foreign language, anxiety, four skills, EFL, Yemeni students

\section{Introduction}

Learning English as a foreign language is not an easy task as students encounter different difficulties. These difficulties can be divided into three factors namely learner factors, teacher factors and language factors (Brown, 2007). Every area of these factors has been investigated extensively particularly the learners' factors in which researchers have investigated even the psychological aspects of the learners. Anxiety is one of the psychological aspects which hinder students from improving their skills when learning English as a second or foreign language (Yamat \& Bidabadi, 2012; Ali \& Fei, 2016; Razak, Yassin, \& Maasum, 2017).

The earlier studies conducted on second language acquisition focused on the cognitive variables such as aptitude, intelligence, and learning styles on the process of second or foreign language learning. However, later studies focused more on emotional factors that might facilitate or hinder the process of learning a second language. Many studies came later concentrated on the effective or personality factors as they play a paramount role in the process of acquiring a second language. Brown (2007) argued that the development of the process of learning and teaching a second language would not be understood without bearing in mind the psychological factors like the personal factors because they have a direct influence on language learning. Researchers have conducted studies on different variables and many of the researchers over the past decades focused on anxiety and its role in the process of second language acquisition (E. K. Horwitz, M. B. Horwitz, \& Cope, 1986; Cheng, 2002; Argaman \& Abu-Rabia, 2002).

Morris, Davis, and Hutchings (1981) argued that anxiety which the learners experience is due to worry and emotionality. Worry refers to the cognitive aspects which the students have during the process of learning such as mental concerns about the learners themselves and negative expectations. Also, the present situation of the learner and the expected consequences raise the level of anxiety. Emotionality refers to physiological-affective elements and the unpleasant feelings which are out of the hand of the learners when they experience anxiety such as tension and nervousness. According to Spielberger (1983), anxiety is the "subjective feeling of tension, apprehension, nervousness, and worry associated with an arousal of the automatic nervous system". There is no specific source of anxiety as it might be caused by different sources (Skehan, 1989). Young (1991) stated that anxiety has different sources which are "personal and interpersonal anxieties; learner beliefs about language 
learning; instructor beliefs about language teaching; instructor-learner interactions; classroom procedures; and language testing". Some studies see that the feeling of anxiety is the outcome of the students' poor abilities related to language learning (Yan \& Horwitz, 2008). Another study is conducted by Lucas, Miraflores, and Go (2011) which sees that the classroom is one source of anxiety for some learners because the students always test their competence and performance during the classes. In addition, the study of Batiha, Noor and Mustaffa (2014) showed that there are many factors that raise language learning anxiety including interaction with teachers, fear of failing the course and vocabulary. Besides, the study of Yassin and Razak (2017) showed that novelty effect raises anxiety among learners of English language.

Scholars have developed many instruments to measure anxiety. According to Horwitz et al. (1986), who developed the Foreign Language Classroom Anxiety Scale (FLCAS), EFL/ESL learners feel anxious inside the classroom for three reasons. The first one is the communication apprehension which means that students might not be able to understand the others during the process of communication; therefore, they cannot express their ideas well. The second aspect is that some students are afraid of being evaluated negatively, so they tend to stay calm and avoid any kind of communication inside the classroom. The third reason is that EFL/ESL students feel anxious when it comes to having test.

The number of the Yemeni students who study English as a foreign language is increasing every year Ezzi (2012). So, it has become important to investigate the problems that might hinder the students from achieving their goals. One of those problems which keep the students unable to use the language and improve their level in second or foreign language is anxiety. Krashen claimed that "the best learning occurs in an environment where anxiety is low" Brown (2007). This area has not been investigated extensively among Yemeni university EFL learners to measure the level of anxiety. Studies need to be conducted to investigate anxiety as well as the possible solutions. This cannot be achieved in one study, so this study is a step in in this area.

One of the problems resulting from anxiety which the students of a foreign language experience is the possible negative effect of anxiety on the academic achievement of the students (Comunian, 1993; Mwamwenda, 1994). There are many studies have been conducted in this regard which proved this view as those who experience high level of anxiety might get low averages whereas those who experience low level of anxiety get high academic averages in the courses which they study at the university. This means that if the students could lower the level of anxiety, they may improve their grades during their study. Studies among Yemeni students about anxiety are needed in order to attract the teachers to this problem and find practical solutions to alleviate the level of anxiety among the students.

Although many studies have been conducted on this area, no similar study has been conducted to investigate anxiety in a broad context which deals with the four skills by using one instrument. This study, therefore, is an attempt to investigate the problem of anxiety among Yemeni university EFL students and relate it to the four skills by using Foreign Language Anxiety Scale (FLAS) developed in this study. There is a need for studies to investigate anxiety in the four skills to have a general overview about the problem of anxiety (Pao, 2013).

\section{Literature Review}

\subsection{Speaking Anxiety}

The most provoking skill for students who study a foreign language is the speaking skill. The researchers have conducted many studies to examine students' anxiety scores and related it to the oral output. Phillips (1992) used the FLCAS, an oral exam, and interviews for collecting data form 44 participants. Philips examined the relationship between the exam scores and foreign language anxiety as well as the relationship between foreign language anxiety and several performance variables. Although the performance of the students in the written test was good, she found that there is a negative relationship between the FLA and the performance of the students as the learners who experience a higher level of anxiety tend to say less, use short units in the process of communication, and give fewer dependent clauses.

Steinberg and Horwitz (1986) investigated the effects which foreign language anxiety has on oral output. The participants were 20 Spanish speaking students studying in a university ESL program. The participants were put in two groups which were high and low and this was according to their language proficiency. Also, the students were assigned randomly into an anxiety condition group and a non-anxiety condition group. The first group included a stern environment and video cameras while the second group was in a relaxing environment without cameras. The participants were asked to talk about three pictures taken from Murry's Thematic Apperception Test (TAT). The result of the study shows that the students who are in the anxiety condition group tend to speak less and interpret less than do those who are in the non-anxiety condition group; this reveals that there is a negative relationship between the foreign language anxiety and the students' performance. 
The relationship between the speaking anxiety and the psychological perception of the learners towards themselves plays an important role in the level of anxiety which students encounter. According to Young (1999), the level of anxiety experienced by the students is associated with the negative thought which the students have towards themselves as well as their fear of failure. Thus, some learners become anxious when it comes to speaking in front of the others especially when they think of the level of proficiency. So, the students who do not trust their abilities and skills when speaking in front of the others always experience higher level of anxiety. The relationship between the mental anxiety and the behavioral performance are connected together as the cognitive anxiety leads to lower behavioral performance. For example, when the students answer a question they might not be able to give the expected answer as their negative thoughts and anxiety might hinder them from giving the expected performance as they will concentrate more on the negative thoughts which distracts them from concentrating on the given task.

Another factor that has influence on speaking anxiety is competitiveness. Several studies have considered competitiveness as one of the factors that have a negative effect on speaking skills. Bailey (1983) as cited in Toth (2007) observed that some students tend to underestimate their abilities when they compare their level with that of the other students which leads to poor speaking performance.

\subsection{Listening Anxiety}

There are many studies that have investigated the relationship between foreign language anxiety, in general, and foreign language listening anxiety, in particular. Although listening anxiety is related to foreign language, it has its own features and it can be studied in isolation (Vogely, 1998). The results of the studies show that the students who experience foreign language anxiety often experience anxiety in listening skill.

Vogely (1998) investigated listening anxiety among 140 intermediate Spanish students through a questionnaire. The result of the study showed that $91 \%$ of the students experience anxiety in listening. Vogely tried to identify the sources of listening anxiety from the responses of the students. The majority of the students $(51 \%)$ stated that the source of anxiety is attributed to some characteristics of the input such as the difficulty of the text they listen to and the nature of the speech; $30 \%$ of the students attributed the problem of listening anxiety to some aspects related to the process of learning a foreign language, $13 \%$ of the students commented that the source of the problem is related to personal factors, and $6 \%$ of the students said that the source of the problem is related to instructional factors.

Kim (2000) used Foreign Language Listening Anxiety Scale (FLLAS) in order to investigate anxiety in listening skill among university EFL students studying English in Korea. The majority of the students stated that they experience anxiety when they listen to the others both inside and outside the classroom. The factor analysis of the FLLAS showed two factors that influence listening anxiety: the absence of self-confidence when listening, and tension and worried over English listening. Among all the items of FLLAS and FLCAS, self-confidence is considered the best predictor of listening proficiency. (Kim, 2000) was conducted in Korea among university EFL students studying English and the result of the study showed that there is a negative relationship between foreign language listening anxiety and listening proficiency.

Elkhafaifi (2005) conducted a similar yet more comprehensive study through which he tried to investigate the relationship between listening anxiety and foreign language anxiety and how it has an effect on listening comprehension performance and the achievement of the students in Arabic courses. Two measures of language assessment as well as background questionnaires were administered to 233 undergraduate and graduate students of Arabic language studying in six universities in the United States. The study adopted the FLCAS and adapted the Foreign Language Reading Anxiety Scale developed by Saito, Garaza, and Horwitz (1999) to measure listening anxiety. The measures which were used in this study are the scores of listening comprehension as well as the final course grades of the students. The researcher found that foreign language anxiety and listening anxiety are related to each other as the students who have higher foreign language anxiety tend to have higher listening anxiety. Also, the study revealed that there is a negative correlation between the level of anxiety and the performance of the students because there is a negative correlation among listening anxiety, listening comprehension grades and final course grades.

There are many variables that affect listening anxiety. Kimura (2008) stated that university majors have influence on foreign language listening anxiety but gender does not have influence on listening anxiety.

\subsection{Reading Anxiety}

There are many studies which have investigated the effect of anxiety on the process of reading as anxiety might have a negative effect on language performance and reading comprehension. To put it simply, those who feel 
anxious might not be able to understand the text and perceive it poorly (Saito et al., 1999).

Some studies investigated the relationship between language proficiency and reading anxiety and the results indicate that students who are in advanced level tend to be less anxious than the other students who are in the beginner or intermediate levels (Liu, 2006).

Studies on anxiety proved that the feeling of anxiety has positive and negative points as well. Those who experience the normal level of anxiety study more as they do not want to harm their confidence and they want to gain high marks. On the contrary, the majority of the students show that the feeling of anxiety has a negative effect on the process of learning as well as on their performance (Horwitz et al., 1986; Sellers, 2000).

Saito et al. (1999) conducted a study to investigate the level of foreign language anxiety which students' experience and compare the result with reading anxiety. In this study, the participants are 383 students who are studying Russian, French, and Japanese university classes. The students took FLCAS and FLRAS and the results of the two measures were compared with the final course grades which the students achieved at the end of the course. The study revealed that the students who experience a higher level of FLA also experience higher level of anxiety in foreign language reading and received low grades in the exams.

Sellers (2000) carried out a study to examine foreign language anxiety and reading anxiety. The researcher adopted the FLCAS and used the adapted version of the Reading Anxiety Scale developed by Zbornick and Wallbrown (1991). The participants are 89 college students studying Spanish language. The students read a passage written in the target language and then received assessments of reading comprehension and a Cognitive Interference Questionnaire. The result shows that the students who experience higher level of anxiety understand less content of the passage and experience more off-task thoughts than the other students. Sellers (2000) confirmed that reading anxiety is a distinctive phenomenon and it needs more attention from the researchers.

\subsection{Writing Anxiety}

Cheng, Horwitz, and Schallert (1999) conducted a study covered 433 students of English in Taiwan in order to explore the correlation between foreign language writing and speaking skills and classroom anxiety. The study collected the data by using FLCAS by Horwitz et al. (1986), Writing Apprehension Test (WAT) by Daly and Miller (1975), and a background questionnaire used to get some information about the history of the students. Also, the study used the final grades of the students as the measurement of achievement in order to compare between them. The correlation was used to compare second language writing anxiety and second language classroom anxiety. It also investigated the correlations between second language writing anxiety and second language speaking and writing achievements. The result of the study showed that the variables of second language classroom anxiety have a significant and negative correlation with English writing and speaking.

Hassan (2001) as cited in Al-Sawalha and Foo (2013) tried to investigate effect of self-esteem on writing anxiety among $182 \mathrm{EFL}$ students in Mansoura University, Department of English, Egypt. Hassan created two questionnaires; the first one is a self-esteem questionnaire and the second one is a writing apprehension one. The data was collected through the writing of the students and the researcher concluded that there is a relationship between self-esteem and writing anxiety, i.e., the students whose self-esteem is low always experience anxiety more than the other students.

Moreover, Daud et al. (2005) conducted a study that aims to explore the relationship between writing performance and anxiety. The study covered 186 third year students whose proficiency level varied. To measure the level of apprehension experienced by the students, the study used the Writing Apprehension Test (WAT). The study found out that the students whose level of proficiency low experience higher level of anxiety and the main cause is their lack of sufficient vocabulary that enables them to express their ideas.

Although there is a relationship between general foreign language anxiety and foreign language writing anxiety, the latter can be studied in isolation since it has its own features distinguishing it from the other types of anxiety (Cheng et al., 1999). In their study, Cheng et al. (1999) investigated foreign language anxiety by using FLCAS and foreign language writing anxiety by using Writing Anxiety Test (WAT) developed by Daly and Miller (1975) and they found that there is a relationship between foreign language anxiety and foreign language writing anxiety but every type has its own constructs.

Cheng (2002) used Second Language Writing Anxiety Inventory (SLWAI) and revealed that the level of anxiety between males and females is different as the females experienced a higher level of anxiety than males. This study found that there are four dimensions affect the writing anxiety: motivation/attitude concerning English writing, confidence concerning English writing, achievement in English writing, and extracurricular efforts to learn English. 
Cheng (2002) also investigated the difference between freshmen, sophomores and juniors. There is no significant statistical difference between them, but the level of anxiety increased with the course level. MacIntyre and Gardner (1989) have a different opinion as the level of anxiety decreased when the students advanced to higher levels of commend of the language. Cheng argued that the level of proficiency might not the paramount factor which determines the decline and rise of language anxiety. He added that when students advance in the language, the teacher require more from the students and the students themselves might realize their mistakes which causes the rise of the level of anxiety.

\section{Methodology}

\subsection{Research Objectives and Questions}

The main objective of this study is to investigate the level of foreign language anxiety among Yemeni university EFL students and it aims to answer the following question:

What is the level of foreign language anxiety among Yemeni university EFL students?

\subsection{Research Setting}

This study is a quantitative study as it uses a questionnaire in order to collect data. It is a survey study which seeks to investigate the level of anxiety which Yemeni university EFL students experience.

A survey research design is adopted as it is the most suitable method for this research. This method has been widely used in the researches which investigated anxiety among EFL learners such as Horwitz et al. (1986) and Saito et al. (1999). Survey research is good at "pinning down the contemporary facts" (Ebel, 1980). Taken into consideration the aims of this research which reveals the level of anxiety among Yemeni students, the survey research design is the most appropriate method.

\subsection{Participants}

The participants are the students of English at the Department of English, Faculty of Arts, Ibb University, Yemen. The method used in this study is stratified random sampling. The students have been divided into four groups; level one, level two, level three, and level four. Also, the students have been divided according to gender to males and females. Then, $20 \%$ of the students have been taken from each level bearing in mind the number of males and females. Singh (2006) argues that it is typical to use $20 \%$ as samples from among the population. The overall number of students is given in Table 1.

Table 1. The number of students in the department of English, faculty of arts, Ibb University, Yemen

\begin{tabular}{cccc}
\hline \multicolumn{2}{l}{ The number of the registered students at the Department of English, Faculty of Arts, Ibb University for the Year } \\
\multicolumn{1}{c}{$\begin{array}{c}2014 \\
\text { Level }\end{array}$} & \multicolumn{3}{c}{ The number of the registered students } \\
\cline { 2 - 4 } One & 105 & Females & The sum \\
Two & 48 & 111 & 216 \\
Three & 74 & 113 & 161 \\
Four & 110 & 100 & 174 \\
The total number & 337 & 116 & 226 \\
\hline
\end{tabular}

The number of students who participated in this study is $20 \%$ of the overall number of students. Thus, the participants in this study are 43 from level one, 32 from level two, 35 from level three, and 45 from level four from both genders. The overall number of the participants is 155 undergraduate students of English language, Department of English, Faculty of Arts, Ibb University, Yemen, as it is shown in Table 2 below: 
Table 2. The number of students participating in the study

\begin{tabular}{llll}
\hline \multicolumn{2}{l}{ The number of students participated in the study } & \\
\hline Level & Males & Females & The sum \\
One & 21 & 22 & 43 \\
Two & 10 & 22 & 32 \\
Three & 15 & 20 & 35 \\
Four & 22 & 23 & 45 \\
The total number & 68 & 87 & 155 \\
\hline
\end{tabular}

\subsection{Research Instrument}

This study uses foreign Language Anxiety Scale (FLAS), as shown in Figure 1 developed specifically for this study which aims to measure the level of anxiety which students of English as a second or foreign language encounter when using the language in speaking, listening, reading, and writing through 48 items.

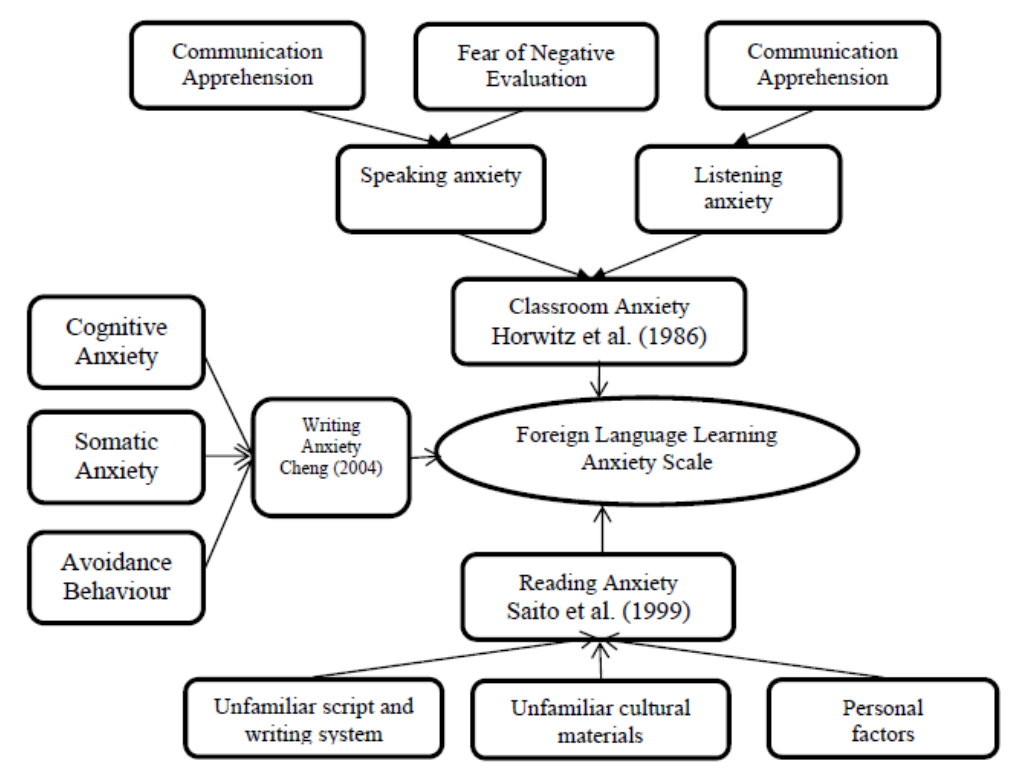

Figure 1. Foreign language learning anxiety scale

This scale has fused three scales with some modifications. The scales which are fused are Foreign Language Classroom Anxiety Scale (FLCAS) by Horwitz et al. (1986), Foreign Language Reading Anxiety (FLRA) developed by Saito et al. (1999) and Foreign Language Writing Anxiety Inventory (FLWAI) developed by Cheng (2004). The first scale FLCAS has been adapted to suit the study. Thirteen items have been taken from the 33 items. Some items have been modified so that the scale investigates anxiety inside the classroom and outside the classroom. These items are $(1,2,7$, and 13). The first scale has been used to investigate the level of anxiety in speaking and listening skills. The second scale FLRAS is adopted in order to investigate the level of anxiety experienced by the students when reading, and it has been used to investigate the reading anxiety which students experienced due to language factors, personal factors and cultural factors. The third scale which has been used is the FLWAI. This scale has 27 items and only 15 items have been taken. These items are used to investigate Somatic Anxiety, Cognitive Anxiety, and Avoidance Behavior. The 15 items have been taken because Cheng (2004) discussed that these 15 items fall directly in the three categories namely Somatic Anxiety, Cognitive Anxiety and Avoidance Behavior, whereas the other items do not fall directly into these three categories.

This study has its own conceptual framework named Foreign Language Anxiety Scale developed specifically for this study. This conceptual framework investigates the general level of anxiety in the four skills. The only scale which investigates the general level of anxiety is FLCAS which concentrates on speaking and listening only. 
MacIntyre and Gardner (1991) defined foreign language anxiety as the feeling of restlessness and tension which the students experience in the four skills namely reading, writing, speaking and listening. A new scale to investigate the general level of anxiety in the four skills is used to help the researcher to have a comprehensive overview about the problem of anxiety in relation to the four skills which students of English try to master.

\subsection{Validity and Reliability}

The new scale was distributed to two professors to revise the items for validity and their comments are taken into consideration. Moreover, the three scales fused in this study have good internal consistency and the final shape of the questionnaire scores .807 in Cronbach Alpha validity which is a very good consistency. Furthermore, Cronbach Alpha validity has been used to measure the internal consistency of the items taken from FLCAS, FLRAS, and FLWAI. The result shows that FLCAS scores .901, FLRAS scores .941 and FLWAI scores .909.

The results of the Cronbach's Alpha validity of the items taken from the three scales and the overall validity of the whole items (FLAS) are summarized in Table 3:

Table 3. Summary for the results of Cronbach's Alpha validity

\begin{tabular}{ll}
\hline Scale & Cronbach's Alpha Score \\
\hline FLCAS & .901 \\
FLRAS & .941 \\
FLWAI & .909 \\
FLAS & .807 \\
\hline
\end{tabular}

\subsection{Procedures}

The researcher took permission from the Head of the Department of English to distribute the questionnaire to the students. A university lecturer who does not teach the students distributed the questionnaire to the students and they all have agreed to respond to the questionnaire items. The lecturer asked the students to write their first reaction without being biased and their answers will be used for the research purpose only in order to increase the reliability of collected data.

\section{Results}

The data is analysed by using SPSS 22 and it shows that the level of foreign language anxiety among Yemeni university EFL students is 138 out of 240 which is considered a moderate level of anxiety. The anxiety has been divided into three levels based on the mean and the standard deviation of the sample by using the technique used by Sellers (2000). These three levels are (high, medium and low). The mean score of the samples is (138.006) and the standard deviation is (20.665). If the mean score of the students is above the real mean plus the standard deviation, it is considered a high level of anxiety. If the mean score of the students is lower than the real mean minus the standard deviation, it is considered a low level of anxiety. If the mean score of the students is between the two ranges, it is considered a medium level of anxiety.

The classification of the levels of anxiety into three levels and the distribution of the samples in the three levels is shown in Table 4:

Table 4. Distribution of the sample into three levels of foreign language anxiety

\begin{tabular}{llllll}
\hline S.N & $\begin{array}{l}\text { Levels of foreign } \\
\text { language anxiety }\end{array}$ & Scores & Score per item & $\begin{array}{l}\text { Number of } \\
\text { Students }\end{array}$ & Percentage (\%) \\
\hline 1 & High Level & 159 and above & $3.31-5$ & 20 & $13 \%$ \\
2 & Medium Level & $118-158$ & $2.45-3.30$ & 107 & $69 \%$ \\
3 & Low Level & 117 and down & $1-2.44$ & 28 & $18 \%$ \\
\hline
\end{tabular}

The result of the study shows that the number of the students who experience high and moderate level of anxiety is $82 \%$ which is considered a high percentage. However, the general level of anxiety is moderate although the students in the University of Ibb, and in Yemen in general, receive their knowledge depending on the traditional 
methods of teaching. They do not have any modern facilities to help them improve their skills as modern methods make the process of learning student-centred and this would be of great asset to them to reduce the level of anxiety.

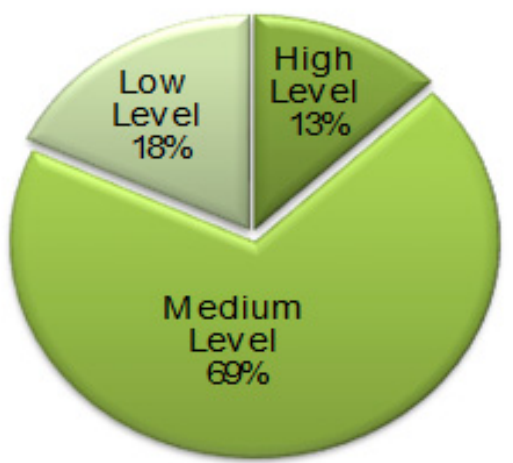

Figure 2. Distribution of the samples into three levels of foreign language anxiety

\section{Discussion}

The number of the items in the scale is 48 items and scores ranged from 48 to 240 . The scores from 48 to 117 (1-2.44) indicate low level of anxiety, scores from 118 to 158 (2.45-3.30) indicate a moderate level of anxiety and scores from 159 to 240 (3.31-5) indicate a high level of anxiety. The general level of anxiety is moderate although $13 \%$ of the students got high level anxiety scores and $18 \%$ of the students got low level of anxiety score. The moderate level of anxiety might be due to the fact that the students have studied English for six years starting from the seventh grade to the twelfth grade in school. Also, some of the students have studied in private schools which means that they have studied English from the first grade to the twelfth grade. Another point must be taken into consideration is that some of the students have studied a diploma in English language before they have joined the university. The familiarity of the students with English language and the time they have spent in the schools or the institutes studying English might help them to alleviate the level of anxiety. In addition, the curriculum which the students have studied from the seventh grade to the twelfth grade is designed by specialists in English language; it is designed under the supervision of the United Kingdom to provide the students with the maximum level of benefit so that students can use English language in every day communicative situations.

Although the general level of anxiety of this study is moderate, the number of the students who are affected by anxiety is $82 \%$ which shows that anxiety is one of the aspects which accompany the process of learning a foreign language. In this connection, Andrade and Williams (2009) investigated the level of anxiety among Japanese students by using FLCAS. The number of the participants was 243 and the result of the study revealed that $75 \%$ of the Japanese students experience anxiety during the process of learning English. It can be observed that the percentage of the number of the Yemeni students who experienced anxiety is greater than the percentage of the number of the Japanese students; this might be due to the process of teaching as Yemeni students do not have the chance to use the facilities which are available in the Japanese classrooms. Traditional teaching methods do not give a chance for the students to be more active inside the classroom and be familiar with the language. Also, Japanese students study English language from the first grade whereas in Yemen the students start the courses of English from the seventh grade; therefore, the previous experience and years of exposer might help the students to reduce the level of anxiety (Dewaele et al., 2008).

Wang (2004) investigated the level of anxiety among the students of English in Mainland China. One of the instruments used in this study is FLCAS which was distributed to the undergraduate students in level one and level two. The result of the analysis reveals that the level of anxiety is relatively high. This might be due to the idea that the students who participated in Wang's study are still in levels one and two whereas the Yemeni undergraduate students who participated in this study are selected randomly from all the levels. Thus, the participants in this study have different levels of proficiency and this might be the reason why the overall average of anxiety is moderate among Yemeni university EFL students. Besides, Truitt (1995) study of Korean students of English language used FLCAS and the result was similar to that of Wang (2005) which reported that the level of foreign language anxiety is relatively high among Korean students of English language. Nahavandi and Mukundan (2013) used the FLCAS in order to investigate the level of anxiety among 548 students belonging to different proficiency levels and the result revealed that the Iranian students experience a higher level of anxiety. These two studies reported high level of anxiety because the students are studying English as a foreign 
language and the system of English language is different from the mother tongue of the Iranian and Korean students. Similarly, $82 \%$ of the participants in this study experience anxiety due to the fact that the Arabic language system is different from the English language system. However, what alleviate the level of anxiety a little bit is that Yemeni university EFL students have a background about English which they gained from pre-university education.

On the other hand, Kunt (1997) conducted two studies and used FLCAS to measure the level of anxiety. The results show that the level of anxiety in the two studies is moderate. The reason which may stand behind this is that Kunt conducted the study in the island of Cyprus which was one of the British colonies. Kunt argued that after the island was occupied by the British, the British effect persisted in the education system and the students have the opportunities to interact with native speakers who still live in the island. The Turkish students, therefore, have the opportunities to listen and to use the language in real communicative situations or through the education in the schools which helped to reduce to the level of anxiety when the students use the language. Students in Yemen do not have the same opportunity to interact with native-speakers which may be the reason that explains why Yemeni students experience high level of anxiety than Turkish students do.

Moreover, the target language might play a role in raising the level of anxiety and this can be noticed in the two studies conducted by Horwitz et al. (1986) among American students of Japanese and (Aida, 1994) of American students of Spanish. The result of the study of (Horwitz et al., 1986) shows a relatively high level of anxiety because the Japanese language has a completely different writing and sound system which makes the process of learning a foreign language difficult. On the other hand, the level of anxiety among the American students of Spanish language is moderate because Spanish language is one of the easiest languages, and the American students are familiar with the writing and the sound system of the Spanish language. The Yemeni university students are in the middle because English language has different sound and writing system from Arabic and this might be the reason for the huge number of Yemeni University EFL who experience language anxiety.

\section{Conclusion}

The aim of the study is to investigate the level of foreign language anxiety among Yemeni university EFL students. The participants in this study are 155 undergraduate students who answered the Foreign Language Anxiety Scale (FLAS) developed specifically for this study. This scale fused three scales namely FLCAS, FLRAS and SLWAI in order to investigate the level of anxiety in the four skills. The scale includes 48 items and the score ranged from 48 to 240 . The real mean of the students is (138.006) and standard deviation is (20.665). If the mean score of the students' responses is above the real mean plus the standard deviation, it is considered high level of anxiety. If the mean score of the students' responses is lower than the real mean minus the standard deviation, it is considered low level of anxiety. If the mean score of the students' responses is between the two ranges, it is considered medium level of anxiety. $13 \%$ of the students came under low level of anxiety, $18 \%$ came under high level of anxiety, and $69 \%$ came under moderate level of anxiety. The result of the analysis for the whole group shows that the students experienced a moderate level of anxiety. The source of anxiety might be due to the difference in the language systems as the English language system is different from Arabic language. However, there are factors that may help to alleviate the level of anxiety to the moderate level including the pre-university experience with English language especially in the basic and secondary school. Universities in Yemen depend on the traditional methods in the process of learning which does not give the students a chance to practice in order to get rid of the level of anxiety. If the process of teaching in Yemeni universities becomes student-centred, the students would be able to deal with the language anxiety.

\section{Implications}

Anxiety is one of the problems which students encounter in the process of learning a second or a foreign language. University teachers should admit that anxiety is one of the problems encountered by Yemeni university EFL students, and it has an effect on the process of learning in general and the academic achievement of the students. Although some studies showed that anxiety might not have a direct effect on learning, the majority of the studies conducted in this regard showed that there is a negative link between anxiety and the overall learning process which can be noticed in the academic achievement of the students (Horwitz et al., 1986; Aida, 1994; Elkhafaifi, 2005). There are many studies that have been conducted to provide some remedies for the problem of anxiety and provided some recommendations for the teachers to help their students overcome this problem.

One of the effective methods that can alleviate the level of anxiety is the Community Language Learning (CLL) developed by Curran (1976). In this approach the students are divided into small groups and preferably less than ten students and then they start to work together and communicate about a specific issue (Koba, Ogawa, \& Wilkinson, 2000). In CLL the text book is not important and the students have the right to choose the topic 
which is suitable to them and through which they can interact which each other. The teacher in this method is considered as a counsellor who receives the questions from the students and then provides some explanations or paraphrasing which the students need to complete their discussion. The aim of this method is to provide the students with the suitable atmosphere in which the students can feel secure and be able to share their ideas, frustration, feelings, anxieties and demands (Koba et al., 2000).

The Natural Approach is developed by Stephen Krasehn and Tracy Terrell in the late 1970s and early 1980s. This approach is a language teaching approach which aims to develop the natural process of learning a language. To achieve this aim, the grammatical rules are no of great importance but the focus is on the students' ability to communicate with the other students in the same group. Students first should receive a huge amount of comprehensible input which enables them after that to express their ideas and thoughts naturally. The most important thing which teachers should take into consideration is to make the atmosphere anxiety free as much as possible. The Natural Approach is seen as an application for Krashen's Monitor Model, but there are many differences since Terrell argued that some emphasis on the grammatical structure can be beneficial to the students. This approach focuses on activities that promote subconscious acquisition of the language and Terrell has divided these activities into four domains: problem-solving activities, games, content activities which enable the students to learn a new subject in the target language, and activities which help the students to personalize the language. The latest one helps the students to express their ideas and thoughts and such activities foster the students to talk about their favourite music and movies, for example. However, this approach has been criticized as it might raise the level of anxiety since the students have to take a role play and must share their ideas with the others.

Furthermore, technology especially Computer Assisted Language Learning (CALL) and cooperative learning are two methods used to make the process of learning student-centred. Utilising these methods in the process of learning may help to reduce the level of anxiety among Yemeni university EFL students.

\section{Acknowledgement}

We would like to express our gratitude and acknowledge the funder of the research and publication: DCP-2017-016/2 Empowering B40 Through 4IR Technology Applications, Universiti Kebangsaan Malaysia.

\section{References}

Aida, Y. (1994). Examination of Horwitz, Horwitz, and Cope's construct of foreign language anxiety: The case of students of Japanese. The Modern Language Journal 78(2), 155-168. https://doi.org/10.1111/j.1540 $-4781.1994 . t b 02026 . x$

Ali, T. T., \& Fei, W. F. (2016). Foreign Language Classroom Anxiety among Iraqi Students and its Relation With Gender and Achievement. International Journal of Applied Linguistics and English Literature, 6(1), 305-310.

Al-Sawalha, A., \& Foo, C. (2013). Mother Tongue Influence on Writing Apprehension of Jordanian Students Studying English Language: Case Study. International Journal of English and Education, 2(1), 46-51.

Andrade, M., \& Williams, K. (2009). Foreign language learning anxiety in Japanese EFL university classes: Physical, emotional, expressive, and verbal reactions. Sophia Junior College Faculty Journal, 29, 1-24.

Argaman, O., \& Abu-Rabia, S. (2002). The influence of language anxiety on English reading and writing tasks among native Hebrew speakers. Language Culture and Curriculum, 15(2), 143-160. https://doi.org/ $10.1080 / 07908310208666640$

Batiha, J., Noor, N. M., \& Mustaffa, R. (2014). Exploring the factors of classroom anxiety in the context of EFL Arab students. International Journal of Social Science and Humanities Research, 2(2), 18-31

Brown, H. D. (2007). Principles of language learning and teaching. New York: Pearson.

Cheng, Y. S. (2002). Factors associated with foreign language writing anxiety. Foreign Language Annals, 35(6), 647-656. https://doi.org/10.1111/j.1944-9720.2002.tb01903.x

Cheng, Y. S. (2004). A measure of second language writing anxiety: Scale development and preliminary validation. Journal of Second Language Writing, 13(4), 313-335. https://doi.org/10.1016/j.jslw.2004.07.001

Cheng, Y. S., Horwitz, E. K., \& Schallert, D. L. (1999). Language anxiety: Differentiating writing and speaking components. Language Learning, 49(3), 417-446. https://doi.org/10.1111/0023-8333.00095

Comunian, A. L. (1993). Anxiety, cognitive interference, and school performance of Italian children. Psychological Reports, 73(3), 747-754. https://doi.org/10.2466/pr0.1993.73.3.747 
Curran, C. A. (1976). Counseling-Learning in Second Language. Apple River: Apple River Press.

Daly, J. A., \& Miller, M. D. (1975). The empirical development of an instrument to measure writing apprehension. Research in the Teaching of English, 9(3), 242-249.

Daud, N. M., Daud, N., \& Abu Kassim, N. L. (2005). Second language writing anxiety: Cause or effect. Malaysian Journal of ELT Research (MELTA), 1-19.

Dewaele, J.-M., Petrides, K. V., \& Furnham, A. (2008). Effects of trait emotional intelligence and sociobiographical variables on communicative anxiety and foreign language anxiety among adult multilinguals: A review and empirical Investigation. Language Learning, 58(4), 911-960. https://doi.org /10.1111/j.1467-9922.2008.00482.x

Ebel, R. L. (1980). Survey research in education: The need and the value. Peabody Journal of Education, 57(2), 126-134. https://doi.org/10.1080/01619568009538278

Elkhafaifi, H. (2005). Listening comprehension and anxiety in the Arabic language classroom. The Modern Language Journal, 89(2), 206-220. https://doi.org/10.1111/j.1540-4781.2005.00275.x

Ezzi, N. A. A. (2012). The impact of gender on the foreign language anxiety of the Yemeni university students. International Journal of Applied Linguistics \& English Literature, 1(2), 65-75.

Horwitz, E. K., Horwitz, M. B., \& Cope, J. (1986). Foreign language classroom anxiety. The Modern Language Journal, 70(2), 125-132. https://doi.org/10.1111/j.1540-4781.1986.tb05256.x

Kim, J. H. (2000). Foreign language listening anxiety: A study of Korean students learning English. Unpublished doctoral dissertation. University of Texas, Austin.

Kimura, H. (2008). Foreign language listening anxiety: Its dimensionality and group differences. JALT Journal, 30(2), 173-196.

Koba, N., Ogawa, N., \& Wilkinson, D. (2000). Using the community language learning approach to cope with language anxiety. The Internet TESL Journal, 6(11).

Kunt, N. (1997). Anxiety and beliefs about language learning: A study of Turkish-speaking university students learning English in North Cyprus. Applied Psycholinguistics, 20, 217-239.

Liu, M. (2006). Anxiety in Chinese EFL students at different proficiency levels. System, 34(3), 301-316. https://doi.org/10.1016/j.system.2006.04.004

Lucas, R. I., Miraflores, E., \& Go, D. (2011). English language learning anxiety among foreign language learners in the Philippines. Philippine ESL Journal, 7, 94-119.

MacIntyre, P. D., \& Gardner, R. C. (1989). Anxiety and Second-Language Learning: Toward a Theoretical Clarification. Language Learning, 39(2), 251-275. https://doi.org/10.1111/j.1467-1770.1989.tb00423.x

MacIntyre, P. D., \& Gardner, R. C. (1991). Methods and Results in the Study of Anxiety and Language Learning: A Review of the Literature. Language learning, 4l(1), 85-117. https://doi.org/10.1111/j.1467 -1770.1991.tb00677.x

Morris, L.W., Davis, M.A., and Hutchings, C.H. (1981). Cognitive and emotional components of anxiety: literature review and a revised worry-emotionality scale. Journal of Educational Psychology, 73(4), 541-555. https://doi.org/10.1037/0022-0663.73.4.541

Mwamwenda, T. S. (1994). Test anxiety and academic achievement among South African university students. Psychological Reports, 75(3f), 1593-1594. https://doi.org/10.2466/pr0.1994.75.3f.1593

Nahavandi, N., \& Mukundan, J. (2013). Foreign Language Learning Anxiety among Iranian EFL learners Along Gender and Different Proficiency Levels. Language in India, 13(1), 133-161.

Pae, T. I. (2013). Skill-based L2 anxieties revisited: Their intra-relations and the inter-relations with general foreign language anxiety. Applied Linguistics, 34(2), 232-252.

Phillips, E. M. (1992). The effects of language anxiety on students' oral test performance and attitudes. The Modern Language Journal, 76(1), 14-26. https://doi.org/10.1111/j.1540-4781.1992.tb02573.x

Razak, N., Yassin, A. A., \& Maasum, N. (2017). Effect of Foreign Language Anxiety on Gender and Academic Achievement among Yemeni University EFL Students. English Language Teaching, 10(2), 73-85. https://doi.org/10.5539/elt.v10n2p73

Saito, Y., Garza, T. J., \& Horwitz, E. K. (1999). Foreign language reading anxiety. The Modern Language 
Journal, 83(2), 202-218. https://doi.org/10.1111/0026-7902.00016

Sellers, V. D. (2000). Anxiety and reading comprehension in Spanish as a foreign language. Foreign Language Annuals, 33(5), 512-521. https://doi.org/10.1111/j.1944-9720.2000.tb01995.x

Singh, Y. K. (2006). Fundamental of Research Methodology and Statistics. New Age International Publishers: New Delhi.

Skehan, P. (1989). Individual differences in second- language learning. London: Edward Arnold.

Spielberger, C. D. (1983). Manual for the State Trait Anxiety Inventory. CA: Consulting Psychologists Press.

Steinberg, F. S., \& Horwitz, E. K. (1986). The effect of induced anxiety on the denotative and interpretive content of second language speech. Tesol Quarterly, 20(1), 131-136. https://doi.org/10.2307/3586395

Truitt, S. N. (1995). Anxiety and beliefs about language learning: A study of Korean university students learning English. Unpublished $\mathrm{PhD}$ thesis, The University of Texas at Austin, Austin.

Vogely, A. J. (1998). Listening comprehension anxiety: Students' reported sources and solutions. Foreign Language Annals, 31(1), 67-80. https://doi.org/10.1111/j.1944-9720.1998.tb01333.x

Wang, N. (2004). Beliefs about language learning and foreign language anxiety: A study of university students learning English as a foreign language in Mainland China. Unpublished Master's thesis. University of Victoria.

Yamat, H., \& Bidabadi, F. S. (2012). English language learning anxiety among Iranian EFL freshman university learners. Research Journal of Applied Sciences, 7(8), 413-420. https://doi.org/10.3923/rjasci.2012.413.420

Yan, J. X., \& Horwitz, E. K. (2008). Learners' perceptions of how anxiety interacts with personal and instructional factors to influence their achievement in English: A qualitative analysis of EFL learners in China. Language Learning, 58(1), 151-183. https://doi.org/10.1111/j.1467-9922.2007.00437.x

Yassin, A. A., \& Razak, N. A. (2017). Investigating the Relationship Between Foreign Language Anxiety in the Four Skills and Year of Study Among Yemeni University EFL Learners. 3L: Language, Linguistics, Literature ${ }^{\circledR}, 23(3)$.

Young, D. J. (1991). Creating a Low-Anxiety Classroom Environment: What Does Language Anxiety Research Suggest?. The Modern Language Journal, 75(4), 426-437. https://doi.org/10.1111/j.1540-4781.1991.tb 05378.x

Young, D. J. (1999). Affect in foreign language and second language learning: A practical guide to creating a low-anxiety classroom atmosphere. Boston: McGraw-Hill.

Zbornik, J. J., \& Wallbrown, F. H. (1991). The development and validation of a scale to measure reading anxiety. Reading Improvement, 28(1), 2.

\section{Appendix A}

\section{Foreign Language Learning Anxiety Scale}

Directions: Statements 1 through 48 refers to how you feel about English when you read, write, or communicate with others. For each statement, please indicate whether you (1) strongly disagree, (2) disagree, (3) neither agree nor disagree, (4) agree, or (5) strongly agree by marking the appropriate number on the line following each statement. Please give your first reaction to each statement and mark one answer for each statement.

SD = Strongly Disagree, $\mathbf{D}=$ Disagree, $\mathbf{N}=$ Neutral, $\mathbf{A}=$ Agree, $\mathbf{S A}=$ Strongly Agree

\begin{tabular}{|c|c|c|c|c|c|c|}
\hline NO. & Questions & $\mathrm{SD}$ & $\mathrm{D}$ & $\mathrm{N}$ & A & $\mathrm{SA}$ \\
\hline 1 & I never feel quite sure of myself when I am speaking in a foreign language. & 1 & 2 & 3 & 4 & 5 \\
\hline 2 & I start to panic when I have to speak without preparation in a foreign language. & 1 & 2 & 3 & 4 & 5 \\
\hline 3 & It embarrasses me to volunteer answers in my language class. & 1 & 2 & 3 & 4 & 5 \\
\hline 4 & *I would not be nervous speaking the foreign language with native speakers. & 1 & 2 & 3 & 4 & 5 \\
\hline 5 & *I feel confident when I speak in foreign language. & 1 & 2 & 3 & 4 & 5 \\
\hline 6 & I am afraid that my language teacher is ready to correct every mistake I make. & 1 & 2 & 3 & 4 & 5 \\
\hline
\end{tabular}




\begin{tabular}{|c|c|c|c|c|c|c|}
\hline 7 & feel very self-conscious about speaking the foreign language in front of others. & 1 & 2 & 3 & 4 & 5 \\
\hline 8 & I get nervous and confused when I am speaking in English. & 1 & 2 & 3 & 4 & 5 \\
\hline 9 & $\begin{array}{l}\text { I feel overwhelmed by the number of rules I have to learn to speak a foreign } \\
\text { language. }\end{array}$ & 1 & 2 & 3 & 4 & 5 \\
\hline 10 & $\begin{array}{l}\text { I am afraid that the other students will laugh at me when I speak the foreign } \\
\text { language. }\end{array}$ & 1 & 2 & 3 & 4 & 5 \\
\hline 11 & $\begin{array}{l}\text { It frightens me when I don't understand what the teacher is saying in the foreign } \\
\text { language. }\end{array}$ & 1 & 2 & 3 & 4 & 5 \\
\hline 12 & I get upset when I don't understand what the teacher is correcting. & 1 & 2 & 3 & 4 & 5 \\
\hline 13 & $\begin{array}{l}\text { I get nervous when I don't understand every word the other person says in } \\
\text { English. }\end{array}$ & 1 & 2 & 3 & 4 & 5 \\
\hline 14 & $\begin{array}{l}\text { I get upset when I am not sure whether I understand what I am reading in } \\
\text { English }\end{array}$ & 1 & 2 & 3 & 4 & 5 \\
\hline 15 & $\begin{array}{l}\text { When reading English, I often understand the words but still can't quite } \\
\text { understand what the author is saying. }\end{array}$ & 1 & 2 & 3 & 4 & 5 \\
\hline 16 & I feel intimidated whenever I see a whole page of English in front of me. & 1 & 2 & 3 & 4 & 5 \\
\hline 17 & $\begin{array}{l}\text { I am nervous when I am reading a passage in English when I am not familiar } \\
\text { with the topic. }\end{array}$ & 1 & 2 & 3 & 4 & 5 \\
\hline 18 & I get upset whenever I encounter unknown grammar when reading English. & 1 & 2 & 3 & 4 & 5 \\
\hline 19 & $\begin{array}{l}\text { When reading English, I get nervous and confused when I don't understand } \\
\text { every word. }\end{array}$ & 1 & 2 & 3 & 4 & 5 \\
\hline 20 & It bothers me to encounter words I can't pronounce while reading English. & 1 & 2 & 3 & 4 & 5 \\
\hline 21 & $\begin{array}{l}\text { By the time you get past the funny letters and symbols in English, it's hard to } \\
\text { remember what you're reading about. }\end{array}$ & 1 & 2 & 3 & 4 & 5 \\
\hline 22 & I usually end up translating word by word when I'm reading English. & 1 & 2 & 3 & 4 & 5 \\
\hline 23 & $\begin{array}{l}\text { I am worried about all the new symbols you [I] have to learn in order to read } \\
\text { English. }\end{array}$ & 1 & 2 & 3 & 4 & 5 \\
\hline 24 & English culture and ideas seem very foreign to me. & 1 & 2 & 3 & 4 & 5 \\
\hline 25 & $\begin{array}{l}\text { You have to know so much about English history and culture in order to read } \\
\text { English. }\end{array}$ & 1 & 2 & 3 & 4 & 5 \\
\hline 26 & $\begin{array}{l}\text { When I'm reading English, I get so confused I can't remember what I'm } \\
\text { reading. }\end{array}$ & 1 & 2 & 3 & 4 & 5 \\
\hline 27 & *I enjoy reading English. & 1 & 2 & 3 & 4 & 5 \\
\hline 28 & *I feel confident when I am reading in English. & 1 & 2 & 3 & 4 & 5 \\
\hline 29 & *Once you get used to it, reading English is not so difficult. & 1 & 2 & 3 & 4 & 5 \\
\hline 30 & The hardest part of learning English is learning to read. & 1 & 2 & 3 & 4 & 5 \\
\hline 31 & $\begin{array}{l}\text { I would be happy just to learn to speak English rather than having to learn to } \\
\text { read as well. }\end{array}$ & 1 & 2 & 3 & 4 & 5 \\
\hline 32 & $\begin{array}{l}\text { I don't mind reading to myself, but I feel very uncomfortable when I have to } \\
\text { read English aloud. }\end{array}$ & 1 & 2 & 3 & 4 & 5 \\
\hline 33 & $\begin{array}{l}\text { *I am satisfied with the level of reading ability in English that I have achieved } \\
\text { so far. }\end{array}$ & 1 & 2 & 3 & 4 & 5 \\
\hline 34 & I feel my heart pounding when I write English. & 1 & 2 & 3 & 4 & 5 \\
\hline 35 & My mind often goes blank when I start to work on an English composition. & 1 & 2 & 3 & 4 & 5 \\
\hline 36 & I tremble or perspire when I write English compositions under time pressure. & 1 & 2 & 3 & 4 & 5 \\
\hline
\end{tabular}




\begin{tabular}{|c|c|c|c|c|c|c|}
\hline 37 & $\begin{array}{l}\text { My thoughts become jumbled when I write English compositions under time } \\
\text { constraint. }\end{array}$ & 1 & 2 & 3 & 4 & 5 \\
\hline 38 & I often feel panic when I write English compositions under time constraint. & 1 & 2 & 3 & 4 & 5 \\
\hline 39 & I freeze up when unexpectedly asked to write English compositions & 1 & 2 & 3 & 4 & 5 \\
\hline 40 & I usually feel my whole body rigid and tense when I write English compositions. & 1 & 2 & 3 & 4 & 5 \\
\hline 41 & *I often choose to write down my thoughts in English. & 1 & 2 & 3 & 4 & 5 \\
\hline 42 & $\begin{array}{l}\text { *I usually seek every possible chance to write English compositions outside of } \\
\text { class. }\end{array}$ & 1 & 2 & 3 & 4 & 5 \\
\hline 43 & *Whenever possible, I would use English to write compositions. & 1 & 2 & 3 & 4 & 5 \\
\hline 44 & *I don't worry that my English compositions are a lot worse than others'. & 1 & 2 & 3 & 4 & 5 \\
\hline 45 & $\begin{array}{l}\text { I'm afraid that the other students would deride my English composition if they } \\
\text { read it. }\end{array}$ & 1 & 2 & 3 & 4 & 5 \\
\hline 46 & $\begin{array}{l}\text { *I don't worry at all about what other people would think of my English } \\
\text { compositions. }\end{array}$ & 1 & 2 & 3 & 4 & 5 \\
\hline 47 & $\begin{array}{l}\text { I'm afraid of my English composition being chosen as a sample for discussion in } \\
\text { class. }\end{array}$ & 1 & 2 & 3 & 4 & 5 \\
\hline 48 & *I'm not afraid at all that my English compositions would be rated as very poor. & 1 & 2 & 3 & 4 & 5 \\
\hline
\end{tabular}

*These Items are positive so the scores should be reversed

\section{Copyrights}

Copyright for this article is retained by the author(s), with first publication rights granted to the journal.

This is an open-access article distributed under the terms and conditions of the Creative Commons Attribution license (http://creativecommons.org/licenses/by/4.0/). 